\title{
Applying Graph Theory to Design Networks of Protected Areas: Using Inter-Patch Distance for Regional Conservation Planning
}

\author{
Renato Crouzeilles ${ }^{1,2 *}$, Maria Lucia Lorini ${ }^{2,3}$ \& Carlos Eduardo de Viveiros Grelle ${ }^{1}$
}

\author{
${ }^{1}$ Laboratório de Vertebrados, Departamento de Ecologia, Universidade Federal do Rio de Janeiro - UFRJ, \\ Rio de Janeiro, RJ, Brazil \\ 2 Programa de Pós-Graduação em Ecologia, Instituto de Biologia, Universidade Federal do Rio de Janeiro - UFRJ, \\ Rio de Janeiro, RJ, Brazil \\ ${ }^{3}$ Laboratório de Gestão da Biodiversidade, Departamento de Botânica, Universidade Federal do Rio de Janeiro - UFRJ, \\ Rio de Janeiro, RJ, Brazil
}

\begin{abstract}
Protected Areas alone may not be large enough to sustain viable populations; thus an alternative is establishing effective networks of protected areas (NPAs). When data on functional connectivity are scarce, landscape structure is viable way to evaluate landscape connectivity. Here we applied the graph approach at the regional scale (Rio de Janeiro state) to design NPAs to conserve several terrestrial mammal species. We used Euclidean and effective distances to compare the number of connections for each protected area. We found that inter-patch distance is a useful metric to design NPAs. Moreover, some protected areas are critically isolated, as indicated by the effective distance. Although several studies use data and models of high specificity, most of them are local and few can be immediately applied for conservation purposes. The methodology used here can help in planning NPAs in a straightforward way providing practitioners with simple analyses and few landscape data.
\end{abstract}

Key words: Atlantic Forest, Broad Scale, Conservation Planning, GIS, Landscape Ecology.

\section{Introduction}

Today the main strategy used to avoid habitat loss involves the creation of protected areas (Brooks et al. 2009). Two basics components that have been evaluated to analyze the effectiveness of protected areas are: the representativeness of biodiversity features (e.g. ecosystems, species, populations), and the persistence of ecological/evolutionary processes (e.g. biotic interactions, natural disturbance and landscape connectivity) (Tang et al. 2011). A promising initiative to enhance the long-term persistence of species is the effective implementation of networks of protected areas (henceforth NPAs). Establishing NPAs is important because protected areas alone may not be large enough to allow the persistence of native populations (Crooks \& Sanjayan 2006), and because deforestation rates are usually high outside protected areas, increasing their isolation (Brooks et al. 2009). Thus, NPAs are designed to increase the available area protected for species and decrease the isolation between protected areas through landscape connectivity.

\footnotetext{
*Send correspondence to: Renato Crouzeilles Laboratório de Vertebrados, Departamento de Ecologia, Universidade Federal do Rio de Janeiro - UFRJ, CP 68020, CEP 21941-590, Rio de Janeiro, RJ, Brasil e-mail: rcpr@biologia.ufrj.br
}

Landscape connectivity may facilitate or challenge species movement between habitat patches (Taylor et al. 2006). It can be categorized into structural connectivity, which represents the physical arrangement of landscape elements; and functional connectivity, which represents the organism's response to landscape structures, being species-specific and dependent on the landscape itself (Tishendorf \& Fahrig 2000). At one hand, structural connectivity can be evaluated through inter-patch distance, as well as by density, complexity and quality of corridors and stepping stones; and even through matrix permeability (Metzger \& Décamps 1997). Functional connectivity, on the other hand, depends on the gap-crossing capability of the species (the species capability to transpose the matrix; Awade \& Metzger, 2008), as well as on costs associated to species dispersal random walk behavior (Zollner \& Lima 1999; Tishendorf \& Fahrig 2000). In some cases, landscape structure is the only way to assess landscape connectivity (Taylor et al. 2006), given that the analysis of organism's responses requires detailed data (Tishendorf \& Fahrig 2000; Pinto \& Keitt 2009; Crouzeilles et al. 2010). For regions with few available data about species' movements and gap-crossing abilities, landscape structure properties such as inter-patch distance and matrix permeability can be useful parameters 
to establish general guidelines to design NPAs for multiple species in fragmented landscapes.

Habitat loss and fragmentation per se are among the main causes of vertebrate species loss due to reduction of their population sizes in tropical forests, such as the Brazilian Atlantic Forest (Grelle et al. 1999). This biome is one of the world's hottest Biodiversity Hotspot (Laurance 2009), with only 11.4 to $16 \%$ of its original vegetation cover remaining (Ribeiro et al. 2009). In order to preserve remaining Atlantic Forest habitats in Brazil, protected areas have been created under two classes of protection, which corresponds to the categories I-IV and V-VI of the IUCN (Brooks et al. 2009). The former, the so-called "strictly protected areas" (hereafter SPAs), has as main goal increase protection on biodiversity and; while the second (sustainable-use areas) allow for different types and levels of human use, having biodiversity conservation as a secondary objective. Currently, both classes of protected areas protect together only $10 \%$ of the geographic distribution of around $75 \%$ of terrestrial mammal species within the Atlantic Forest (Albuquerque et al. 2011). Therefore, identifying and establishing NPAs is one way to promote the persistence of mammal species in this global imperiled region.

Here we applied a graph theory approach at the regional scale to design NPAs for the state of Rio de Janeiro focusing on terrestrial mammal species. We compared the number of connections for each SPA according to two graph approaches: the euclidean distance model (based on a binary map of habitat/non-habitat) and the effective distance model (based on a cost map of the resistance of landscape structures), trying to improve the configuration of the NPAs. We discuss our results in terms of structural metrics as well as ecological processes related to long-term persistence and gap-crossing or inter-patch movements of terrestrial mammal from the Atlantic Forest.

\section{Methods}

\section{Study area and collection data}

The state of Rio de Janeiro is located in the southeastern part of the Brazilian Atlantic Forest, with a human population estimated in more than 15 million people (http://ibge. gov.br/estadosat/perfil.php, accessed on 27 August 2009). Currently, it presents less than $20 \%$ of its original forest cover (SOS Mata Atlântica \& INPE 2002), distributed mostly in forest remnants surrounded by a heterogeneous matrix of different anthropogenic uses.

We performed connectivity analysis based on the current forest cover obtained from a vegetation map, at the scale of 1:50000 in vector format (SOS Mata Atlântica \& INPE 2002). This map, derived from Landsat 5/TM and 7/ETM+ images, identifies forest remnants with at least 10 ha (Figure 1). We downloaded the land cover/land use map on MMA (http:// mapas.mma.gov.br/mapas/aplic/probio, accessed on 10
November 2008), and the SPAs map on IBAMA (www. ibama.gov.br/patrimonio/, accessed on 5 March 2008). All geographic information system data were used in South American Datum 1969 and were converted in the Albers projection to allow for area proper calculation.

\section{Modeling graphs}

In the graph approach there are general graph operations related to connection between nodes and related to losses and gains of nodes (Urban \& Keitt 2001). Here we focused on the former operations. Links can be specified at different levels of precision: as a binary representation (0/1), as euclidian distances, or as effective (cost) distances. Although the links based on effective distances are conceptually appealing, in many cases their application can be precluded by difficulties to parameterize cost surfaces, given that functional connectivity is species- and landscape-specific (Urban et al. 2009). Therefore, we used structural metrics to designing NPAs for terrestrial mammal species.

We designed graphs to encompass selected pairs of SPAs at the state of Rio de Janeiro and their surrounding landscape elements. Two criteria were used to select the pairs of SPAs (we selected these pairs because it does not make sense to analyze all possible pairs considering that distances between SPAs often would be larger than $350 \mathrm{~km}$ ). First, we searched for pairs of SPAs at Rio de Janeiro within a radius of $100 \mathrm{~km}$, the largest distance between two boundaries of nearest SPAs (Itatiaia NP x Tinguá BR; see Table 1). Second, we created a concentric buffer on pairs of SPAs to ensure that the shortest pathway between them does not match another SPA. For example, if to connect a specific pair of SPAs (e.g. SPA1 to SPA3) the species needs to use another SPA located in the middle of the pathway used (e.g. SPA2), it means that the shortest distance that need to be searched are among SPA1 - SPA2 and SPA2 - SPA3. After, as gap-crossing data are scarce for Atlantic Forest species (Crouzeilles et al. 2010), we used two approaches to search for the shortest pathway between each selected pairs of SPAs: an euclidean distance and a simplified effective distance model. The euclidean model builds inter-patch distance through a linear estimation between nearest-neighbor nodes on binary maps. Here nodes are habitat patches (represented by SPAs and remnant forests), and while non-nodes are non-habitat patches that represent the matrix. Within the multiple possible paths to be traveled between nodes, we found the shortest pathway between each pair of SPAs and after the largest inter-patch distance to be traveled on the shortest pathway. We considered this largest inter-patch distance as a surrogate for the shortest gap-crossing of mammal species, a required parameter to build NPAs. Therefore, an inter-patch distance equal to zero means that the analyzed pair of SPAs is physically connected (e.g. when SPAs were united by its boundaries or directly linked by forest remnants). This model is very simple and returns the maximum number of connected pairs of SPAs. 


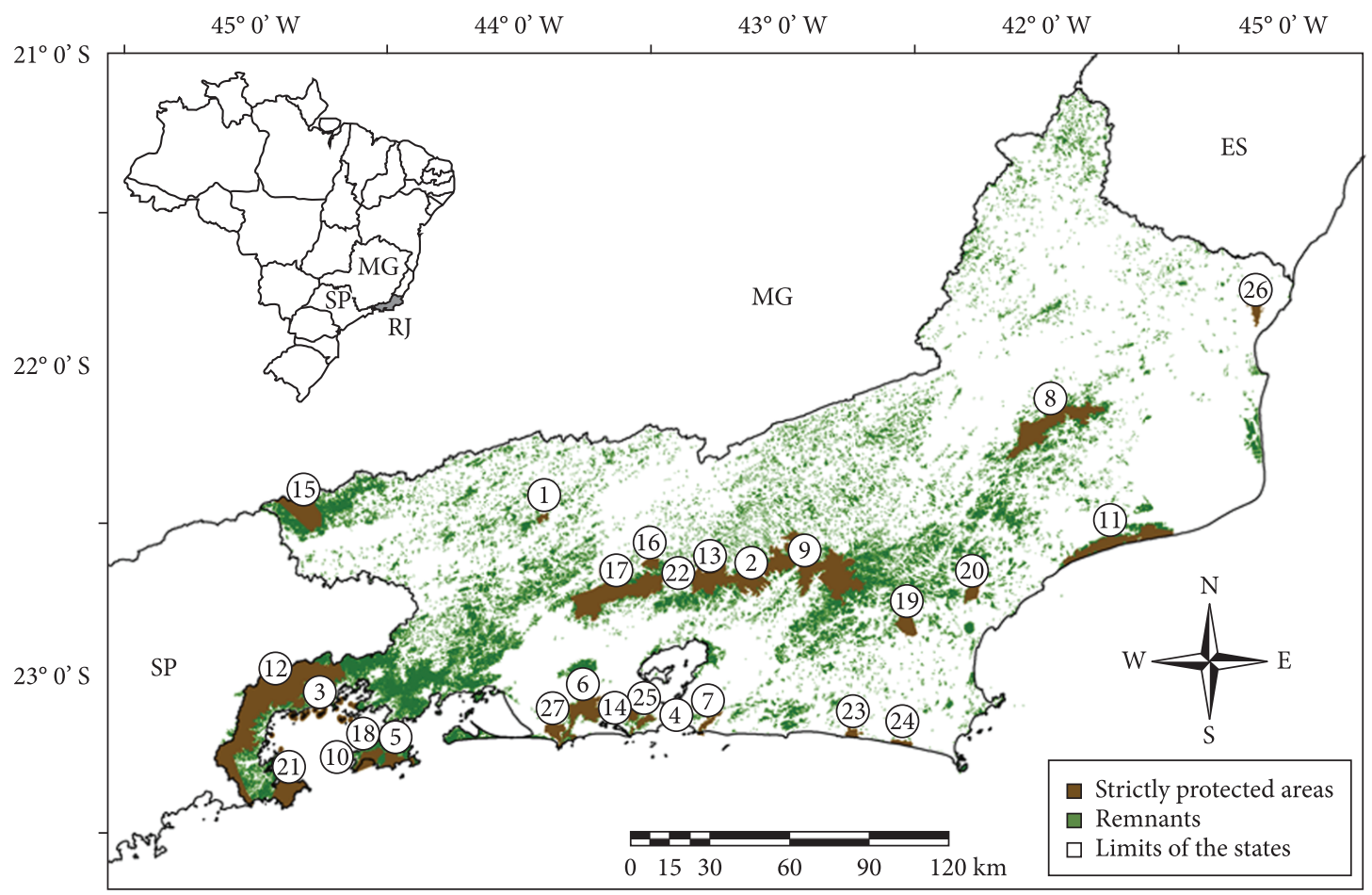

Figure 1. Strictly protected areas (SPAs) and forest remnants of the Atlantic Forest ( $\geq 10$ ha) at the state of Rio de Janeiro, southeastern Brazil. SPAs and their size: (1) Serra da Concórdia SP (804 ha), (2) Paraíso ES (4920 ha), (3) Tamoios ES (8,700 ha), (4) Chacrinha SP (13 ha), (5) Ilha Grande SP (5594 ha), (6) Pedra Branca SP (12,500 ha), (7) Serra da Tiririca SP (1800 ha), (8) Desengano SP (22,400 ha), (9) Três Picos SP (46,350 ha), (10) Aventureiro SP (1300 ha), (11) Jurubatiba NP (14,860 ha), (12) Bocaina NP (100,000 ha), (13) Serra dos órgãos NP (11,800 ha), (14) Tijuca NP (3200 ha), (15) Itatiaia NP (30,000 ha), (16) Araras BR (2068 ha), (17) Tinguá BR (2600 ha), (18) Praia do Sul BR (3600), (19) Poço das Antas BR (5000 ha), (20) União BR (3126 ha), (21) Juatinga ER (8000 ha), (22) Alcobaça ER (4300 ha), (23) Jacarepiá ER (1250 ha), (24) Massambaba SR (1680 ha), (25) Grajaú SP (55 ha), (26) Guaxindiba ES (3260 ha), (27) Guaratiba BR (2800 ha).

The effective distance model, on the other hand, considers the resistance that some landscape elements present on the mammal movements. To improve model generality, we inserted in the effective distance model only the landscape elements that affect the movements of the organisms in a similar way. First, to create a cost map, resistance values (in cost units) were assigned to land cover classes as follow: habitat (forest patches) $=0$; permeable matrix (non-forest vegetation, agrosystems) $=1.2$; and impermeable matrix (extensive water surfaces - $500 \mathrm{~m}$ or wider - and urban areas $)=12,000$. As matrix permeability varies widely among mammal species, we tuned the parameters to assign a resistance for the permeable matrix slightly higher than the null resistance of habitat patches. In the same way, 12,000 units were assigned to represent the total resistance to movements over extensive water surfaces and urban surfaces, in order to block pathways that cross these elements. Next, the cost map was superimposed to the map of NPAs resulting from the euclidean model in order to identify pairs of SPAs in which the shortest pathway crossed impermeable matrix. Then, we excluded pairs identified as above explained, instead of searching for a new shortest pathway, which may return values much larger than performed by mammal species. For all other pairs, for which only permeable matrix crosses the shortest pathway, we recalculated the largest inter-patch distance.
Therefore, our effective distance model remained based on euclidean model results, which are more plausible to dealing with metrics of structural connectivity. Further, false assumptions about the resistance of landscape elements may result in misleading conclusions in conservation plans focused on multiple species.

We used a paired t-test to compare whether the number of connections for each SPAs varied according to the model used. For this comparison we considered only the connections that were not excluded in the effective distance model - as we are interested in knowing a particular model may improve the configuration of NPAs.

We defined the pairs of SPAs and generate cost maps for the effective model using ArcGIS 9.3 (ESRI 2008). We used JmatrixNet software (Bodin et al. 2006) to analyze the shortest pathway between SPAs as well as the largest inter-patch distance among them.

\section{Results}

The Euclidean model indicated 46 pairs of SPAs of which 11 pairs were physically connected (Table 1). Average largest inter-patch distance was $1.57 \mathrm{~km}(\mathrm{SD} 1.61 ; \mathrm{n}=46)$. Tinguá BR and Pedra Branca SP presented the highest value of largest inter-patch distance among all pairs $(6.8 \mathrm{~km})$. 
Table 1. Pairs of strictly protected areas (SPAs) connected in the euclidean distance model at the state of Rio de Janeiro.

\begin{tabular}{|c|c|c|c|c|}
\hline $\begin{array}{c}\text { Pairs of } \\
\text { protected areas }\end{array}$ & $\begin{array}{c}\text { Distance between } \\
\text { boundaries of } \\
\text { SPAs }(\mathbf{k m})\end{array}$ & $\begin{array}{c}\text { Euclidean } \\
\text { model } \\
(\mathrm{km})\end{array}$ & $\begin{array}{c}\text { Effective } \\
\text { model } \\
(\mathrm{km})\end{array}$ & $\begin{array}{l}\text { Total } \\
\text { area } \\
\text { (ha) }\end{array}$ \\
\hline Itatiaia NP x Tinguá BR & 100.00 & 2.1 & 2.51 & 56,000 \\
\hline Itatiaia NP x Serra da Concordia SP & 83.99 & 0.7 & 0.85 & 30,804 \\
\hline Bocaina NP x Tamoios ES & 1.5 & 0.2 & 0.24 & 108,700 \\
\hline Bocaina NP x Juatinga ER & 8.40 & 0 & 0 & 108,000 \\
\hline Bocaina NP x Guaratiba BR & 81.25 & 2.9 & 3.48 & 102,800 \\
\hline Bocaina NP x Pedra Branca SP & 86.24 & 2.9 & 3.48 & 112,500 \\
\hline Bocaina NP x Serra da Concordia SP & 93.8 & 1.2 & 1.44 & 100,804 \\
\hline Bocaina NP x Tinguá BR & 95.73 & 1 & 1.2 & 12,600 \\
\hline Tamoios ES x Guaratiba BR & 71.76 & 2.9 & 3.48 & 11,500 \\
\hline Tamoios ES x Tinguá BR & 92.52 & 1 & 1.2 & 34,700 \\
\hline Tamoios ES x Serra da Concordia SP & 96.86 & 1.2 & 1.44 & 9,504 \\
\hline Aventureiro SP x Praia do Sul BR* & 0 & 0 & 0 & 4,900 \\
\hline Ilha Grande SP x Praia do Sul BR ${ }^{\star}$ & 0.72 & 0 & 0 & 9,194 \\
\hline Serra da Concordia SP x Tinguá BR & 30.09 & 2.2 & 2.64 & 26,804 \\
\hline Serra da Concordia SP x Araras BR & 43.61 & 2.3 & 2.76 & 2,872 \\
\hline Tinguá BR x Araras BR & 0.93 & 0 & 0 & 28,068 \\
\hline Tinguá BR x Pedra Branca SP & 25.82 & 6.8 & - & 38,500 \\
\hline Tinguá BR x Alcobaça ER & 8.2 & 0.2 & 0.24 & 30,300 \\
\hline Tinguá BR x Serra dos Órgãos NP & 10.94 & 0.2 & 0.24 & 37,800 \\
\hline Araras BR x Alcobaça ER & 10.68 & 1 & - & 6,368 \\
\hline Guaratiba BR x Pedra Branca SP & 0.22 & 0 & 0 & 15,300 \\
\hline Pedra Branca SP x Tijuca NP & 7.93 & 3 & - & 15,700 \\
\hline Pedra Branca SP x Grajaú SP & 11.44 & 4.5 & - & 12,555 \\
\hline Tijuca NP x Grajaú SP & 0 & 0 & 0 & 3,255 \\
\hline Aventureiro SP x Ilha Grande SP* & 3.86 & 0 & 0 & 6,894 \\
\hline Tijuca NP x Chacrinha SP & 1.93 & 1.8 & - & 3,213 \\
\hline Serra da Tiririca SP x Serra dos Órgãos NP & 43.72 & 2.5 & 3 & 13,600 \\
\hline Serra da Tiririca SP x Jacarepiá ER & 50.34 & 1.2 & 1.44 & 3,050 \\
\hline Alcobaça ER x Serra dos Órgãos NP & 0.99 & 0 & 0 & 16,100 \\
\hline Serra dos Órgãos NP x Três Picos SP & 0 & 0 & 0 & 58,150 \\
\hline Três Picos SP x Paraíso ES & 0 & 0 & 0 & 51,270 \\
\hline Três Picos SP x Jacarepiá ER & 43.78 & 2.1 & 2.52 & 47,600 \\
\hline Três Picos SP x Poço das Antas BR & 17.70 & 0.6 & 0.72 & 51,350 \\
\hline Três Picos SP x União BR & 39.82 & 0.4 & 0.48 & 49,476 \\
\hline Três Picos SP x Desengano SP & 70.15 & 0.8 & 0.96 & 68,750 \\
\hline Paraíso ES x Serra dos Órgãos NP & 5.63 & 0 & 0 & 16,720 \\
\hline Jacarepiá ER x Poço das Antas BR & 38.20 & 2.1 & 2.52 & 6,250 \\
\hline Jacarepiá ER x Massambaba SR & 11.36 & 3.1 & - & 2,930 \\
\hline Massambaba SR x Poço das Antas BR & 37.81 & 3.2 & - & 6,680 \\
\hline Poço das Antas BR x União BR & 21.03 & 1.3 & 1.56 & 8,126 \\
\hline Poço das Antas BR x Desengano SP & 65.65 & 1 & 1.2 & 27,400 \\
\hline União BR x Desengano SP & 45.18 & 1.1 & 1.32 & 25,526 \\
\hline União BR x Jurubatiba NP & 32.24 & 2.2 & 2.64 & 17,986 \\
\hline Desengano SP x Jurubatiba NP & 42.3 & 2.3 & 2.76 & 37,260 \\
\hline Desengano SP x Guaxindiba ES & 68.27 & 5.4 & - & 25,660 \\
\hline Jurubatiba NP x Guaxindiba ES & 80.63 & 4.9 & - & 18,120 \\
\hline Mean & 36.67 & $1.57(1.04)^{\star *}$ & 1.25 & 32.21 \\
\hline Standard deviation $( \pm)$ & 34.06 & $1.61(1.01)^{\star *}$ & 1.21 & 31.30 \\
\hline
\end{tabular}

NP - National Park, SP - State Park, ES - Ecological Station, BR - Biological Reserve, ER - Ecological Reserve. The distance between the boundaries of SPAs, the largest inter-patch distance in shortest pathway between the pair in euclidean distance model (km), in the effective distance model ( $\mathrm{km})$ and the total area (ha) of the pairs of protected areas.* Three pairs are connected, but were isolated from other areas because they are located on the island of Ilha Grande off the south coast of state of Rio de Janeiro. ${ }^{* *}$ Values in parentheses considered only the same SPA pairs formed also in the effective model $(\mathrm{n}=37)$ 
However, the distance between the boundaries of these two protected areas was only $26 \mathrm{~km}$, which is less than the average distance considering all pairs $(36.6 \mathrm{~km}$; SD 34.06). Tinguá BR had the largest number of connections $(n=8)$, and all SPAs presented at least one connection.

Effective model indicated 37 pairs of SPAs (Table 1). Nine pairs found in the previous model were excluded, because five were disrupted by extensive water surfaces and four by urban areas. Similar to the euclidean models, 11 pairs were physically connected. Average of largest inter-patch distance was $1.25 \mathrm{~km}$ (SD 1.21; $\mathrm{n}=37$ ). Three pairs had $3.48 \mathrm{~km}$ of largest inter-patch distance, which was the highest among all pairs. However, the distances between the boundaries of the SPAs in these three pairs are not among the largest distances recorded. The average distance considering all pairs was $38.67 \mathrm{~km}$ (SD 35.32). Tinguá BR remained as the SPA with the highest number of connections $(n=7)$. Massambaba ER, Guaxindiba ES and Chacrinha SP did not present any connection. Moreover, Pedra Branca SP was the protected area that lost more connections in this model $(\mathrm{n}=3$; Table 1$)$.

The design of NPAs increased total area size (ha) of SPAs (Figure and Table 1). Comparing the same pairs of SPAs that had assessed values of the largest inter-patch distance $(\mathrm{n}=37)$, the results of effective model always showed largest inter-patch distances than the Euclidean model (Table 1). The number of connections for each SPA in the two models was significantly different $(\mathrm{t}=3.703 ; \mathrm{n}=27 ; \mathrm{p}=0.001)$, being higher for euclidean model, which has the maximum number of connected pairs of SPAs.

\section{Discussion}

As the effectiveness of NPAs to the maintenance of ecological processes has not been well documented, it is essential to comprehend the contribution of NPAs for biodiversity conservation (Tang et al. 2011). The long-term persistence of species is a vital ecological process that must be evaluated into the NPAs through some approaches such as: connectivity or reserve selection (e.g. maximize biodiversity representation within minimum protected areas system). According to the connectivity models used here, NPAs at the state of Rio de Janeiro must allow the increase of the total area of protected habitat, which can be critical for the species' long-term persistence (Figure 1 and Table 1). Thus, both approaches are going in different directions, whereas connectivity tends to enhance the cohesion of protected areas, given importance for small areas that are important as connection elements; reserve selection tends to maximize the representation of biodiversity in a minimum number of areas that have enough size to sustain viable populations, regardless of cohesiveness of protected areas system.

The models used here were simple and based on metrics of structural connectivity. When data of functional connectivity are insufficient, metrics based on the habitat spatial location are useful. Average largest inter-patch distance in the shortest pathway was $1.57 / 1.04 \mathrm{~km}$ (euclidean model, $\mathrm{n}=46 / 37$ ) and $1.25 \mathrm{~km}$ (effective model, $\mathrm{n}=37$ ), which were close of the average distance between fragments in Atlantic Forest (ca. 1.4 km; Ribeiro et al. 2009). Therefore, even simple models based on inter-patch distance can be useful to establish general guidelines to design NPAs for multiple species, considering that this metric is one of the main variables influencing gap-crossing and inter-patch movements (Awade \& Metzger 2008).

Moreover, as the debate about the management of protected areas has been focused on the conservation of multiple species, and species have different functional responses according their biology, Urban et al. (2009) suggested the construction of independent graphs for several species, and their overlap in spatial solutions to find priority sites for composing the NPAs. Indeed, robust models are available for measure functional distances, such as least-cost (e.g. Pinto \& Keitt 2009) and circuit theory (e.g. McRae 2006). However, these models need data with high specificity that are difficult to be obtained (Tishendorf \& Fahrig 2000; Pinto \& Keitt 2009) and promotes computational bottlenecks when working with several thousand nodes (Urban et al. 2009), what is frequent at the regional scale. For the Atlantic Forest, data on inter-patch movement of mammals are available for only ten species of small mammals (Crouzeilles et al. 2010). In the absence of such data, our results of largest inter-patch distance in the shortest pathway between SPAs may be used to/as: (1) a surrogate for shortest gap-crossing for mammal species, a parameter required to design NPAs between pairs of SPAs, (2) identify which pairs of SPAs may be connected for species that have gap crossing information, and (3) a base to indicate pairs of SPAs, which will be connected after studies of gap crossing and inter-patch movements for other species.

Our models presented significant difference in the number of connection for each SPA. Tinguá BR had more connections in both models, but some SPAs presented radical changes in number of connection from the Euclidian to the effective model. Pedra Branca SP lost more connections, however, Massambaba ER; Guaxindiba ES; and Chacrinha SP lost all connections and became isolated. This information must receive special attention in conservation. Although both models were general, effective model proved to be better in assessing the effectiveness of the NPAs, as this model identified protected areas that are in critical situation of isolation.

We would like to make some policy recommendations based on our results. First, natural remnants must be managed to allow functional connection between SPAs and reducing isolation distances between them. Currently, more than $80 \%$ of the Atlantic Forest remnants have an area of less than 50 ha (Ribeiro et al. 2009). Individually, these fragments have little ecological value, but when connected they may provide sufficient habitat for different species (Andersson 
\& Bodin 2009). Second, to solve questions related to NPAs, the principles from the graph theory must be applied to model networks at regional or broad scales. Third, the methodology used here can help NPAs throughout simple analysis and with few landscape and species data.

We showed that mostly SPAs at Rio de Janeiro are not connected and therefore, NPAs must be establishing effective to enhance the long-term persistence of species. Our results showed that inter-patch distance may be a surrogate for gap-crossing of mammal species, and the largest inter-patch distance in the shortest pathway between SPAs may help create NPAs that complies with the means of conservation biology and management plans by either allowing to identify important forest remnants to be protected (assuring connectivity) or areas to be restored.

\section{Acknowledgements}

We thank J. Prevedello, L. Oliveira, R. Loyola and two anonymous reviewers and for comments suggestions in the manuscript. We also thank FAPERJ, CNPq and CI-Brazil for financial support, and CAPES for providing a scholarship to $\mathrm{RC}, \mathrm{CNPq}$ for granting a productivity fellowship to CEVG, and PNPD/CAPES for the postdoctoral fellowship awarded to MLL.

\section{References}

Albuquerque FS et al., 2011. Identification of critical areas for mammal conservation in the Brazilian Atlantic Forest Biosphere Reserve. Natureza \& Conservação, 9:73-78. http:// dx.doi.org/10.4322/natcon.2011.009

Andersson E \& Bodin Ö, 2009. Practical tool for landscape planning? An empirical investigation of network based models of habitat fragmentation. Ecography, 32:123-132. http://dx.doi.org/10.1111/j.1600-0587.2008.05435.x

Awade M \& Metzger JP, 2008. Using gap-crossing capacity to evaluate functional connectivity of two Atlantic Rainforest birds and their response to fragmentation. Austral Ecology, 33:863-871. http://dx.doi. org/10.1111/j.1442-9993.2008.01857.x

Bodin Ö et al., 2006. The value of small size: Loss of forest patches and ecological thresholds in Southern Madagascar. Ecological Applications, 16:440-51. http://dx.doi. org/10.1890/1051-0761(2006)016[0440:TVOSSL]2.0.CO;2

Brooks TM, Wright SJ, \& Sheil D, 2009. Evaluating the Success of Conservation Actions in Safeguarding Tropical Forest Biodiversity. Conservation Biology, 23:1448-1457. PMid:20078645. http://dx.doi. org/10.1111/j.1523-1739.2009.01334.x

Crooks KR \& Sanjayan M, 2006. Connectivity conservation. Cambridge: Cambridge University Press. http://dx.doi. org/10.1017/CBO9780511754821
Crouzeilles R, Lorini ML \& Grelle CEV, 2010. Deslocamento na matriz para espécies da mata Atlântica e a dificuldade da construção de perfis ecológicos. Oecologia Australis, 14:875-903. http://dx.doi.org/10.4257/oeco.2010.1404.06

Environmental Systems Research Institute - ESRI, 2008. ArcView 9.3. Redlands: ESRI.

Fundação SOS Mata Atlântica \& Instituto Nacional de Pesquisas Espaciais - INPE, 2002. Atlas dos remanescentes florestais da Mata Atlântica - Período de 1995-2000. São Paulo: Fundação SOS Mata Atlântica. Relatório Final.

Grelle CEV et al., 1999. The question of scale in threat analysis: A case study with Brazilian mammals. Animal Conservation, 2:149-152. http://dx.doi.org/10.1111/j.1469-1795.1999. tb00060.x

Laurance WF, 2009. Conserving the hottest of the hotspots. Biological Conservation, 142:1137. http://dx.doi.org/10.1016/j. biocon.2008.10.011

McRae BH, 2006. Isolation by resistance. Evolution, 60:1551-1561.

Metzger JP \& Décamps H, 1997. The structural connectivity threshold: an hypothesis in conservation biology at the landscape scale. Acta Ecologica, 18:1-12. http://dx.doi. org/10.1016/S1146-609X(97)80075-6

Pinto N \& Keitt TH, 2009. Beyond the least cost path: evaluating corridor robustness using a Graph-theoretic approach. Landscape Ecology, 24:253-266. http://dx.doi.org/10.1007/ s10980-008-9303-y

Ribeiro MC et al., 2009. Brazilian Atlantic Forest: How much is left and how is the remaining forest distributed? Implications for conservation. Biological Conservation, 142:1141-1153. http://dx.doi.org/10.1016/j.biocon.2009.02.021

Tang ZY et al., 2011. Effectiveness of protected areas in maintaining plant production. PLoS ONE, 6(4):1-8. PMid:21552560. PMCid:3084248. http://dx.doi.org/10.1371/ journal.pone.0019116

Taylor PD, Fahrig L \& With KA, 2006. Landscape Connectivity: A return to the basics. In Crooks K \& Sanjayan MA (eds.). Connectivity Conservation. Cambrige University Press: Cambridge. p. 29-46. http://dx.doi.org/10.1017/ CBO9780511754821.003

Tishendorf L \& Fahrig L, 2000. On the usage and measurement of landscape connectivity. Oikos, 90:7-19. http://dx.doi. org/10.1034/j.1600-0706.2000.900102.x

Urban DL et al., 2009. Graph models of habitat mosaics. Ecology Letters, 12:260-273. PMid:19161432. http://dx.doi. org/10.1111/j.1461-0248.2008.01271.x

Urban DL \& Keitt TH, 2001. Landscape connectivity: A Graphtheoretic perspective. Ecology, 82:1205-1218. http://dx.doi. org/10.1890/0012-9658(2001)082[1205:LCAGTP]2.0.CO;2

Zollner PA \& Lima SL, 1999. Search strategies for landscape-level interpatch movements. Ecology, 80:1019-1030. http://dx.doi. org/10.1890/0012-9658(1999)080[1019:SSFLLI]2.0.CO;2 